\title{
IN VITRO OVICIDAL ACTIVITY OF TWO CHEMOTYPES OF YARROW (ACHILLEA MILLEFOLIUM L.) ESSENTIAL OIL AGAINST OVINE GASTROINTESTINAL NEMATODE EGGS
}

\author{
Filip Štrbac ${ }^{1 *}$, Antonio Bosco ${ }^{2}$, Alessandra Amadesi ${ }^{2}$, Laura Rinaldi ${ }^{2}$, \\ Dragica Stojanović ${ }^{1}$, Nataša Simin ${ }^{3}$, Dejan Orčićc \\ Ivan Pušićc ${ }^{4}$, Slobodan Krnjajićs ${ }^{5}$ Radomir Ratajac ${ }^{4}$ \\ ${ }^{1}$ Department of Veterinary Medicine, University of Novi Sad, \\ Faculty of Agriculture, Novi Sad, Republic of Serbia \\ ${ }^{2}$ Department of Veterinary Medicine and Animal Production, \\ University of Naples Federico II, Naples, Italy \\ ${ }^{3}$ Department of Chemistry, Biochemistry and Environmental Protection, \\ University of Novi Sad, Faculty of Sciences, Novi Sad, Republic of Serbia \\ ${ }^{4}$ Scientific Veterinary Institute "Novi Sad", Novi Sad, Republic of Serbia \\ ${ }^{5}$ Institute for Multidisciplinary Research, University \\ of Belgrade, Belgrade, Republic of Serbia
}

\section{Abstract}

Economic losses caused by the gastrointestinal nematodes of small ruminants have been on increase mainly due to anthelmintic resistance. Therefore, researchers from all around the world are searching for new, alternative strategies to control these parasites. Being a valuable natural resource, medicinal plants and their products have emerged as a viable option. This study aimed to evaluate the in vitro ovicidal activity of two chemotypes of yarrow (Achillea millefolium L.) essential oil against ovine gastrointestinal nematode eggs. Nematode eggs obtained from the faeces of naturally infected sheep on two farms located in Southern Italy were subjected to the egg hatch test. On both farms, the coproculture examination identified the presence of species belonging to four genera of sheep gastrointestinal nematodes: Haemonchus, Trichostrongylus, Teladorsagia and Chabertia. The main components of the yarrow essential oil identified by GC-MS analysis were 1,8-cineole (41.69\%), camphor $(8.37 \%)$ and trans-chrysanthenyl acetate (4.90) in the oil type 1 and $\beta$-pinene (28.53\%), $\beta$-caryophyllene (18.71\%) and 1,8-cineole $(11.69 \%)$ in type 2 . The in vitro ovicidal activity was evaluated at six oil concentrations 
$(50,12.5,3.125,0.781,0.195$ and $0.049 \mathrm{mg} / \mathrm{mL})$, whereby the inhibitory effect of the essential oil on egg hatchability varied from 46.5 to $99.5 \%$ (type 1) and from 69.6 to $97.25 \%$ (type 2). All concentrations tested showed a significantly higher efficacy compared to the negative control $(\mathrm{p}<0.0001)$. The inhibitory effect on egg hatching was similar $(\mathrm{p}>0.05)$ to the positive control (98.0\%) at concentrations of $50 \mathrm{mg} / \mathrm{mL}(99.5 \%), 12.5 \mathrm{mg} / \mathrm{mL}(98.0 \%)$ and $3.125(95.25 \%)$ of the oil type 1 , and at concentrations of $50 \mathrm{mg} / \mathrm{mL}(97.25 \%)$ and $12.5 \mathrm{mg} / \mathrm{mL}(90.0 \%)$ of the type 2 . The obtained results suggested that the A. millefolium essential oil has high anthelmintic potential, especially the chemotype rich in 1,8-cineole and camphor, which requires confirmation in further in vivo studies.

Keywords: Achillea millefolium, essential oil, sheep, phytotherapy, gastrointestinal nematodes

\title{
IN VITRO OVICIDNA AKTIVNOST DVA TIPA ETARSKOG ULJA HAJDUČKE TRAVE (ACHILLEA MILLEFOLIUM L.) PROTIV JAJA GASTROINTESTINALNIH NEMATODA OVACA
}

\author{
Filip Štrbac ${ }^{1^{*}}$, Antonio Bosco ${ }^{2}$, Alessandra Amadesi ${ }^{2}$, Laura Rinaldi ${ }^{2}$, \\ Dragica Stojanović ${ }^{1}$, Nataša Simin ${ }^{3}$, Dejan Orčicíc, \\ Ivan Pušić c $^{4}$, Slobodan Krnjajićs ${ }^{5}$, Radomir Ratajac ${ }^{4}$ \\ ${ }^{1}$ Departman za veterinarsku medicinu, Univerzitet u Novom \\ Sadu, Poljoprivredni fakultet, Republika Srbija \\ ${ }^{2}$ Departman za veterinarsku medicinu i animalnu proizvodnju, \\ Univerzitet u Napulju Federiko II, Napulj, Italija \\ ${ }^{3}$ Departman za hemiju, biohemiju i zaštitu životne sredine, Univerzitet \\ u Novom Sadu, Prirodno-matematički fakultet, Republika Srbija \\ ${ }^{4}$ Naučni institut za veterinarstvo „Novi Sad“, Novi Sad, Republika Srbija \\ ${ }^{5}$ Institut za multidisciplinarna istraživanja, Univerzitet \\ u Beogradu, Beograd, Republika Srbija
}

\section{Kratak sadržaj}

Ekonomski gubici koje prouzrokuju gastrointestinalne nematode malih preživara u poslednje vreme rastu usled razvoja rezistencije na antihelmintike. Zbog toga istraživači širom sveta tragaju za novim, alternativnim 
strategijama za kontrolu ovih parazita. Kao dragocen prirodan resurs, lekovite biljke i njihovi proizvodi nametnuli su se kao moguća opcija. Cilj ovog istraživanja je bio utvrditi in vitro ovicidnu aktivnost dva hemotipa etarskog ulja hajdučke trave (Achillea millefolium L.) protiv jaja gastrointestinalnih nematoda ovaca. Jaja nematoda su izolovana iz fecesa prirodno inficiranih ovaca sa dve farme locirane u južnoj Italiji kako bi se sproveo test izleganja larvi (eng. egg hatch test). Na obe farme, koprokulturološkim ispitivanjima je utvrđeno prisustvo vrsta četiri roda gastrointestinalnih nematoda ovaca: Haemonchus, Trichostrongylus, Teladorsagia i Chabertia. Najzastupljenije komponente etarskog ulja hajdučke trave identifikovane GC-MS analizama bile su 1,8-cineol (41,69\%), kamfor (8,37\%) i trans-hrizantenil acetat $(4,90 \%)$ u ulju tipa 1 , odnosno $\beta$-pinen (28,53\%), $\beta$-kariofilen (18,71\%) i 1,8-cineol $(11,69 \%)$ u tipu 2. In vitro ovicidna aktivnost je testirana u šest različitih koncentracija $(50,12.5,3.125,0.195$ i $0.049 \mathrm{mg} / \mathrm{mL})$. Inhibitorni efekat etarskog ulja na izleganje jaja je varirao od 46,5-99,5\% (ulje tipa 1), odnosno 69,6-97,25\% (tip 2), dok je kod svih ispitivanih koncentracija efekat bio značajno veći u poređenju sa negativnom kontrolom $(\mathrm{p}<0.0001)$. Pored toga, inhibitorni efekat na izgleganje larvi je bio sličan $(\mathrm{p}>0.05)$ pozitivnoj kontroli (98,0\%) pri koncentracijama $50 \mathrm{mg} / \mathrm{mL}$ (99,5\%), 12,5 mg/ $\mathrm{mL}(98,0 \%)$ i $3,125 \mathrm{mg} / \mathrm{mL}(95,25 \%)$ ulja tipa 1, odnosno pri koncentracijama od $50 \mathrm{mg} / \mathrm{mL}(97,25)$ i $12,5 \mathrm{mg} / \mathrm{mL}(90,0 \%)$ kod tipa 2. Dobijeni rezultati ukazuju na to da etarsko ulje hajdučke trave, naročito tipa 1 koje je bogato 1,8-cineolom i kamforom, poseduje visok antihelmintički potencijal, što zahteva potvrdu u daljim in vivo ispitivanjima.

Ključne reči: Achillea millefolium, etarsko ulje, ovce, fitoterapija, gastrointestinalne nematode

\section{INTRODUCTION}

Gastrointestinal nematodes (GIN) nowadays present a major problem faced by sheep producers worldwide (Sweeney et al., 2016; Kaplan et al., 2020). Their parasitism leads to various negative effects in animals such as impaired health, reduced food intake, weight loss, weakness as well as low production and fertility which results in significant economic losses (Macedo et al., 2010; D'ambola et al., 2018). Synthetic anthelmintics have long been used successfully to minimize these losses (Kaplan et al., 2020). However, as a consequence of unjustifiable use, reduced dosages and increased application rates of these 
drugs, anthelmintic resistance (AR) may develop (Macedo et al., 2010; Kebede, 2019). Unfortunately, some reports suggest that anthelmintic resistance in sheep GIN has already become a global problem, with a various single and multi-drug resistant species presented all over the world (Dolinska et al., 2014).

Many scientific reports indicate an increase in helminth resistance to the commonly used classes of anthelmintic drugs such as benzimidazoles, tetrahydropyrimidines, imidazothiazoles and macrocyclic lactones in the European Union (Sargison et al., 2001; Borgsteede et al., 2007; Sargison et al., 2008). Among sheep GIN, the most resistant species to these drugs are Haemonchus contortus, Teladorsagia and Trichostrongylus (Papadopoulos et al., 2012). Trichostrongylus species resistant to ivermectin were also identified in Serbia (Simin et al., 2014). The economic losses occurred as a result of gastrointestinal parasitism in sheep are great but hard to quantify, although there have been some attempts in individual parameters. For example, total annual production losses in 33 European countries due to GIN infection in meat sheep industry are estimated on $€ 345$ million, which corresponds to approximately $8.5 \%$ of the total production (Mavrot et al., 2016). The true, total costs of gastrointestinal parasitism in sheep, especially after the development of anthelmintic resistance, are likely to be much larger. For these reasons, researchers around the world are now focused on devising new, alternative strategies including genetic resistance control, pasture management, crop-livestock integration, nutrition adjustment, biological regulation (use of fungi and bacteria), vaccine production and some others (Zeineldin et al., 2018; Pinto et al., 2019).

Recently, the use of botanical anthelmintic has often been mentioned as a possibly effective means to combat AR. Medicinal herbs and their products have been used for different purposes since ancient times and are currently considered a more sustainable and more easily accessible therapeutic and/or preventive alternative to synthetic drugs (Ferreira et al., 2018). Choosing appropriate plant species for anthelmintic examinations and other pharmacological studies is not easy, but it is an important step in the development of a new, potential drug. This step should be based on solid operational strategies and relevant ethnopharmacological/chemotaxonomic data (Ferreira et al., 2018). One of the most mentioned and tested plant products are essential oils (EOs) (Andre et al., 2018). These natural, highly volatile metabolic secretions of plants are complex mixture of different compounds with great biotechnological and pharmaceutical potential (Ferreira et al., 2016; Butnariu and Sarac, 2018). Thus, it was assumed that some of these ingredients could also have anthelmintic activity, which was proven for different terpene and terpenoid compounds such as linalool, eugenol, geraniol, citronellal, menthol, thymol, 
carvacrol, citral, $\alpha$-pinene, myrcene and many others (Ferreira et al., 2016). These compounds are often found in essential oils of various plants.

Yarrow (Achillea millefolium L. sensu lato) is a perennial, medicinal plant from Asteraceae family, widely distributed throughout the temperate and boreal zones of the Northern Hemisphere. It represents a highly polymorphic group of closely related species, subspecies, microspecies and hybrids, which differ in the ploidy level, morphology and chemical composition. These various taxa are difficult to differentiate one from another and are classified together in pharmacopeia monographs under the name Achillea millefolium L. (Baczek et al., 2015). Thus, chemical composition of commercially available products obtained from A. millefolium can significantly differ from each other. Yarrow is a well-known medicinal herb used widely in folk medicine in many cultures worldwide for the treatment of spasmodic gastrointestinal, hepatobiliary and gynaecological disorders, against inflammation and to promote wound healing (Ali et al., 2017; Majid et al., 2018). Infusions, decoctions or fresh juices made from yarrow are also frequently used in Serbia for the same medical purposes (Pljevljakušić et al., 2017). In an ethno-veterinary practice, there are some reports about the use of aerial parts of yarrow for treatment of mastitis, sternal abscess and wounds in ruminants (Lans et al., 2007). Nevertheless, little is known about the use of yarrow in veterinary medicine.

The efficiency of $A$. millefolium against various pathogens was documented. El-Kalamouni et al. (2017) demonstrated high antibacterial activity of $A$. millefolium EO against B. subtilis, B. cereus, St. aureus, S. typhimurium and S. agona and antifungal action against $R$. stolonifer, $V$. dahliae, C. gloeosporioides, $B$. cinerea and A. niger. Some studies showed positive activity of yarrow essential oil even against E. coli and S. enteritidis (Ahmadi-Dastgerdi et al., 2017). Finally, A. millefolium extracts were also found to possess an antiparasitic effect against some protozoa, such as B. canis (Guz et al., 2019), Blastocystis spp. (Özbilgin et al., 2013) and Leishmania spp. (Soosaraei et al., 2017) as well as against parasitic leeches (Bahmani et al., 2014). A. millefolium $\mathrm{EO}$ was found to have a trypanocidal effect (Santoro et al., 2007) and an effect against some neglected diseases (Luna et al., 2019). Therefore, EO from A. millefolium may be assumed to also have anthelmintic properties. Considering the severity and wideness of the problem of $\mathrm{AR}$, the aim of this study was to evaluate the in vitro ovicidal activity of two chemotypes of A. millefolium EO (against sheep GIN using the egg hatch test (EHT). 


\section{MATERIAL AND METHODS}

\section{Essential oil and GC-MS analysis}

In the present study, two samples of A. millefolium EO belonging to different chemotypes (type 1 and type 2) were used. Sample of type 1 was purchased from Institute of Field and Vegetable Crops, Novi Sad, Serbia, while sample of type 2 was purchased from BIOSS, Serbia in 2019. Qualitative and semi-quantitative chemical characterization of EOs was done by gas chromatography (GC) and mass spectrometry (MC), using Agilent Technologies $6890 \mathrm{~N}$ gas chromatography coupled with Agilent Technologies 5975B electron ionization mass-selective detector. The following technical conditions were applied: injection volume of EO $1 \mu \mathrm{L}$; injector temperature $250^{\circ} \mathrm{C}$; split ratio 1:10; carrier gas helium; flow rate: $1 \mathrm{~mL} / \mathrm{min}$; capillary column: HP-5 $(30 \mathrm{~m} \times 0.25 \mathrm{~mm}$, $0.25 \mu \mathrm{m})$; temperature program $50-270^{\circ} \mathrm{C}$; ion source temperature $230^{\circ} \mathrm{C}$; electron energy $70 \mathrm{eV}$; quadrupole temperature $150^{\circ} \mathrm{C}$. The compounds were identified by comparison of their mass spectra with data libraries (Wiley Registry of Mass Spectral Data, 7th ed. and NIST/EPA/NIH Mass Spectral Library 05) and confirmed by comparison of linear retention indices with literature data (Adams, 2012). The relative amounts of components, expressed in percentages, were calculated by the normalization procedure according to peak area in the total ion chromatogram.

\section{Extraction of eggs and egg hatch test}

In vitro ovicidal activity of $A$. millefolium $\mathrm{EOs}$ was examined in the egg hatch test (EHT), which is commonly used to test the efficacy of antiparasitic drugs and the presence of parasitic resistance (Robles-Perez et al., 2014). The in vitro test was performed at the Regional Centre for Monitoring of Parasitosis (CREMOPAR), located in Eboli (Campania Region, Salerno Province), Italy. Faecal samples were collected from sheep of two farms, which are located in the same district. GIN eggs were recovered from faeces collected directly from the rectal ampulla of sheep with natural mixed infection. The faecal samples were processed within $2 \mathrm{~h}$ of collection by using the recovery technique with some modifications (Bosco et al., 2018). Firstly, faecal samples were homogenized and filtered under running water through sieves with a mesh size of 1 $\mathrm{mm}, 250 \mu \mathrm{m}, 212 \mu \mathrm{m}$ and $38 \mu \mathrm{m}$ to separate the eggs from the faeces. Next, the GIN eggs retained on the last sieve were washed and centrifuged for $3 \mathrm{~min}$ at 1500 relative centrifugal force with distilled water, after which the supernatant 
was discarded. In the end, centrifugation was performed using a $40 \%$ sugar solution to float the eggs which are then isolated in new tubes, mixed with distilled water and then centrifuged two more times in order to remove pellets and to get an aqueous solution with eggs.

The EHT was performed as proposed in the used literature with some modification (Ferreira et al., 2018). Twenty-four-well plates, containing aqueous solutions of approximately 150 eggs/well, were used for this experiment. Six different concentrations of A. millefolium EO $(50,12.5,3.125,0.781,0.195$ and $0.049 \mathrm{mg} / \mathrm{mL})$ were emulsified in Tween $80(3 \%, \mathrm{v} / \mathrm{v})$ and completed with distilled water in a final volume of $0.5 \mathrm{~mL} /$ well. After incubation for $48 \mathrm{~h}$ at $27^{\circ} \mathrm{C}$, the number of eggs and first-stage (L1) larvae were counted under an inverted microscope and compared to the controls. The positive control was thiabendazole at a concentration of $0.025 \mathrm{mg} / \mathrm{mL}$, and the negative control was Tween $80(3 \%, v / v)$. The experiment was performed two times with two replicates each, and the results were expressed as the mean percentage of egg hatching.

\section{Coproculture}

In order to determine the genera of GIN in vitro tested on the efficacy of $A$. millefolium EOs, a pooled faecal culture for each farm was made following the protocol described by the Ministry of Agriculture, Fisheries and Food (MAFF, 1986). The third-stage larvae $\left(L_{3}\right)$ were identified based on their morphology (van Wyk and Mayhew, 2013). Identification and percentages of each nematode genera were conducted on $100 \mathrm{~L}_{3}$.

\section{Statistical analysis}

The mean percentage of egg hatching was calculated using the following formula (Macedo et al., 2019):

$\mathrm{IH}(\%)=$ Number of eggs / (number of eggs + number of larvae $\left.\left(\mathrm{L}_{1}\right)\right) \times 100$

Data on the inhibition of hatchability (IH) for both types were analysed by one-way ANOVA followed by Tukey's test $(\mathrm{p}<0.05)$ to compare values obtained for different concentrations with each other and with controls (+ and -). Two-way ANOVA followed by Bonferroni's test $(\mathrm{p}<0.05)$ was used to compare the results of the same concentration of both tested types of A. millefolium EO (Macedo et al., 2019). The nonlinear correlation coefficient was calculated for both types to express the dose-dependent response (Ferreira et al., 2018). All statistical procedures were performed by using the program GraphPad Prism 


\subsection{2.}

\section{RESULTS}

\section{GC-MS analysis}

Chemical analyses (GC-MS) revealed a rich composition of the two $A$. millefolium EOs. There were some similarities between the types in the presence of some dominant compounds, but their relative percentage differed significantly. In total, GC-MS analyses identified $98.73 \%$ and $97.06 \%$ of the chemical constituents present in the type 1 and type 2, respectively. The total number of compounds (28 in type 1 and 27 in type 2) was similar, but only 15 compounds were identified in both types, while 13 compounds in type 1 and 12 compounds in type 2 were unique for the types. The major identified components were 1,8-cineol (41.69\%), camphor (8.37\%) and trans-chrysanthenyl acetate $(4.90 \%)$ in the type 1 and $\beta$-pinene (28.53\%), $\beta$-caryophyllene $(18.71 \%)$ and 1,8-cineol (11.69\%) in type 2 (Table 1$)$.

Table 1. Chemical composition (\% of total peak area) of two chemotypes of Achillea milefolium essential oil determined by GC-MS analysis

\begin{tabular}{|c|l|c|c|}
\hline \multirow{2}{*}{$\mathrm{AI}^{*}$} & \multicolumn{1}{|c|}{ Compound } & Type 1 & Type 2 \\
\hline 906 & Santolina triene & 0.38 & 0.08 \\
\hline 925 & a-Thujene & - & 0.13 \\
\hline 932 & a-Pinene & 3.09 & 4.15 \\
\hline 947 & Camphene & 1.37 & 0.26 \\
\hline 972 & Sabinene & 1.87 & 5.48 \\
\hline 976 & $\beta$-Pinene & 1.50 & 28.53 \\
\hline 991 & 1,8 -Dehydro cineole & 0.25 & - \\
\hline 998 & $\delta$-2-Carene & 1.40 & - \\
\hline 1016 & a-Terpinene & 2.86 & 0.19 \\
\hline 1024 & p-Cymene & 4.38 & 0.65 \\
\hline 1027 & Limonene & - & 0.87 \\
\hline 1030 & 1,8 -Cineole & 41.69 & 11.69 \\
\hline 1057 & $\gamma$-terpinene & 1.13 & 0.40 \\
\hline 1059 & Artemisia ketone & 4.31 & - \\
\hline 1082 & Artemisia alcohol & 1.57 & - \\
\hline 1087 & Terpinolen & 0.35 & - \\
\hline 1106 & cis-Thujone & 3.28 & - \\
\hline 1115 & trans-Thujone & 2.13 & - \\
\hline 1124 & Chrysanthenone & 2.55 & 0.48 \\
\hline 1138 & trans-Pinocarveol & 0.51 & 1.57 \\
\hline 1143 & Camphor & 8.37 & \\
\hline
\end{tabular}




\begin{tabular}{|c|l|c|c|}
\hline $\mathrm{AI}^{*}$ & \multicolumn{1}{|c|}{ Compound } & Type 1 & Type 2 \\
\hline 1161 & cis-Chrysanthenol & 0.69 & - \\
\hline 1161 & Pinocarvone & - & 0.40 \\
\hline 1164 & Borneol & 3.57 & 0.47 \\
\hline 1176 & Terpinen-4-ol & 3.37 & - \\
\hline 1190 & a-Terpineol & 1.18 & 0.87 \\
\hline 1196 & Myrtenal & 4.90 & 0.54 \\
\hline 1234 & $\begin{array}{l}\text { cis-Chrysanthe- } \\
\text { nyl acetate }\end{array}$ & 0.75 & - \\
\hline 1261 & cis-Chrysanthe- & & - \\
& nyl acetate & 0.22 & - \\
\hline 1285 & Isobornyl acetate & - & 1.30 \\
\hline 1291 & Lavandulyl acetate & - & 1.29 \\
\hline 1384 & Bourbonene & 0.59 & 4.71 \\
\hline 1418 & $\beta$-Caryophyllene & - & 8.08 \\
\hline 1452 & a-Humulene & 0.44 & 0.86 \\
\hline 1480 & Germacrene D & - & 0.44 \\
\hline 1495 & sesquiterpene & - & 2.90 \\
\hline 1513 & sesquiterpene & - & 3.52 \\
\hline 1523 & d-Cadinene & - & \\
\hline 1581 & Caryophyllene oxide & - & \\
\hline 1590 & Viridiflorol & & \\
\hline
\end{tabular}

${ }^{\star}$ Arithmetic retention index

\section{Egg hatch test}

The egg hatch test conducted in this study showed high activity of both types of the A. millefolium essential oil against sheep GIN eggs (Table 2). In total from both farms, the inhibitory effect on hatchability varied from 46.5$99.5 \%$ and $69.5-97.25 \%$ for type 1 and type 2, respectively. All concentrations tested showed a significantly higher efficacy compared to the negative control $(p<0.0001)$. For the few highest concentrations in both types, the effect was similar to that of thiabendazole $(\mathrm{p}>0.05)$. Nevertheless, results showed that there were some differences between obtained values for the same concentrations tested of type 1 and type 2. These differences led to a different dose-dependent inhibitory effect on hatchability, which is more pronounced for type $1\left(\mathrm{r}^{2}=0.9840\right)$ compared to type $2\left(\mathrm{r}^{2}=0.8637\right)$. As can be seen from Table 2, a lower tested concentration in type $1(3.125 \mathrm{mg} / \mathrm{mL})$ was needed for an egg hatching inhibition of $90 \%$ compared to type $2(12.5 \mathrm{mg} / \mathrm{mL})$. 
Štrbac, F. ... et al.: In vitro ovicidal activity of two chemotypes of yarrow...

Table 2. Efficacy (mean \pm standard deviation) of two chemotypes of Achillea millefolium essential oil against sheep nematode egg hatching

\begin{tabular}{|c|c|c|}
\hline Concentration $(\mathrm{mg} / \mathrm{mL})$ & \multicolumn{2}{|c|}{ Inhibition of hatchability (\%) } \\
\cline { 2 - 3 } & Type 1 & Type 2 \\
\hline 50 & $99.50 \pm 1^{\mathrm{Aa}}$ & $97.25 \pm 0.96^{\mathrm{Aa}}$ \\
\hline 12.5 & $98 \pm 1.83^{\mathrm{Aa}}$ & $90 \pm 4.97^{\mathrm{Ab}}$ \\
\hline 3.125 & $95.25 \pm 4.35^{\mathrm{Aa}}$ & $73 \pm 1.63^{\mathrm{Bb}}$ \\
\hline 0.781 & $87.5 \pm 2.65^{\mathrm{Ba}}$ & $72.75 \pm 8.421^{\mathrm{Bb}}$ \\
\hline 0.195 & $49 \pm 1.63^{\mathrm{Ca}}$ & $71.25 \pm 3.30^{\mathrm{Bb}}$ \\
\hline 0.049 & $46.5 \pm 3^{\mathrm{Ca}}$ & $69.50 \pm 3.40^{\mathrm{Bb}}$ \\
\hline Thiabendazole, & $98 \pm 0.82^{\mathrm{Aa}}$ & $98 \pm 0.82^{\mathrm{Aa}}$ \\
\hline $0.025 \mathrm{mg} / \mathrm{mL}(+)$ & & \\
\hline Tween $80(3 \%, \mathrm{v} / \mathrm{v})(-)$ & $16.75 \pm 5.56^{\mathrm{Da}}$ & $16.75 \pm 5.56^{\mathrm{Ca}}$ \\
\hline
\end{tabular}

* Uppercase compares means within each column and lowercase within a row. Different letters indicate significant differences $(p<0.05)$

\section{Coproculture}

On both examined farms, four genera of sheep GIN were identified in coproculture: Haemonchus (53\%), Trichostrongylus (29.5\%), Teladorsagia (14.5\%) and Chabertia (3\%).

\section{DISCUSSION}

Combating anthelmintic resistance requires reliable methods for its detection, as well as those for testing the efficacy of anthelmintic agents (Kebede, 2019). Despite some limitations, the egg hatch test is considered an accurate and reliable test for these purposes (Sargison, 2008). Like other in vitro methods, this is often chosen to be done before in vivo tests because it is neither time consuming nor expensive. Moreover, fewer animals are required for in vitro trials, which also do not include any animal treatment. However, anthelmintic drugs that are effective in vitro are not necessarily such to the same extent in field conditions (Ferreira et al., 2016; Peña-Espinoza, 2018). This particularly refers to ruminants whose gastrointestinal tract may hugely impact the degra- 
dation, transformations or interactions of the applied drugs, which can lead to their inactivity (Hoste et al., 2008). Therefore, in vitro tests are a useful tool for the selection of potential active substances and they are being used as the first step in the development of new anthelmintic agents.

In the present study, the high ovicidal anthelmintic potential of A. millefolium EO against sheep gastrointestinal nematodes was demonstrated. With some differences, primarily reflected in a dose-dependent response, both oil chemotypes showed a high inhibitory effect on nematode egg hatching. There are few literature data that focus on the evaluation of the anthelmintic potential of A. millefolium. Tariq et al. (2008) evaluated the anthelmintic effects of crude aqueous and ethanolic extracts of an entire A. millefolium plant against sheep GIN. In that study, both aqueous (94.44\%) and ethanolic (88.88\%) extracts produced a significant anthelmintic effect on $H$. contortus nematodes by inhibiting their motility. Both extracts were also shown to have a high in vivo anthelmintic potential in the same study, where treatment with $2 \mathrm{~g} / \mathrm{kg}$ resulted in $88.40 \%$ and $76.53 \%$ reduction in faecal egg counts for aqueous and ethanolic extract, respectively. The authors concluded that $A$. millefolium had high potential to be an alternative for anthelmintic treatment in ruminants. However, the investigated extracts are obtained by using polar solvents, thus contain polar compounds which are not present in EOs.

The high anthelmintic potential of both yarrow EOs demonstrated in the present study can be attributed to its chemical composition. As shown earlier, GC-MS analyses showed that both types are rich in compounds of possible pharmacological interest. More importantly, these compounds are also represented in various essential oils with a proven anthelmintic effect against sheep GIN in different studies so far. For instance, 1,8-cineole (eucalyptol) was also the main component of Artemisia lancea (34.56\%), Piper aduncum (55.8) and Rosmarinus officinalis (42.11\%) essential oils which showed high ovicidal and larvicidal potential, mainly against $H$. contortus (Zhu et al., 2013; Oliveira et al., 2014; Pinto et al., 2019). In different relative percentages, 1,8-cineol was also identified in essential oils with anthelmintic activity obtained from another plants such as Mentha piperita (Katiki et al., 2011), Eucalyptus staigeirana (Mesquita et al., 2013), Anthemis nobile and Lavandula officinalis (Ferreira et al., 2018). Similarly, as one of the main components, $\beta$-pinene was identified in P. aduncum (4.7\%) and Citrus aurantifolia (11.86\%) (Oliveira et al., 2014; Ferreira et al., 2018), camphor in A. lancea (16.65\%) and L. officinalis (5.54\%) (Zhu et al., 2013; Ferreira et al., 2018), caryophyllene in Lippia sidoides (10.60\%) (Camurça-Vasconcelos al., 2007), p-cymene in Thymus vulgaris (23.76\%) (Ferreira et al., 2016), a-pinene in R. officinalis (14.76\%) and Juniperus com- 
munis (40.46\%) (Pinto et al., 2019; Štrbac et al., 2020), borneol in Zanthoxylum simulans (18.61\%) (Qi et al., 2015) etc. Other components such as sabinene, terpinen-4-ol, $\gamma$-terpinene, camphene, germacrene $\mathrm{D}$, artemisia ketone were also found in plant essential oils with proven anthelmintic potential. It can be concluded that compounds such as 1,8-cineole (eucalyptol) and camphor are often found in high relative percentages in EOs with proven anthelmintic effect, indicating their high anthelmintic potential. Therefore, the slightly higher activity of the type $1 \mathrm{EO}$, which in lower concentrations inhibited egg hatching by $90 \%$, can be attributed to its higher content of more potent compounds. It is particularly important since a treatment is considered effective in controlling nematodes only if leads to $90 \%$ decrease in egg hatching (Ferreira et al., 2016).

The differences in anthelmintic potential obtained for two A. millefolium EOs can be attributed to their different chemical composition. The difference in EOs chemical composition can derive from different plant material used for EO isolation by two EO producers. Namely, the plant material of A. milefolium used for isolation of EOs probably belongs to different closely related taxa. Additionally, environmental factors (light, precipitation, the site of growth (altitude, latitude), soil properties ( $\mathrm{pH}$, constituents), growing conditions) under which the plants were grown as well as EO isolation methods can significantly influence the yield and chemical composition of EO (Barra, 2009). Other studies also confirmed differences in the chemical composition of EOs depending on plants geographical origin. Djouahri et al. (2015) reported significant variation of the chemical composition of the Tetraclinis articulata EO depending on plant material origin, which led to high variations in EO biological activities. Therefore, the results obtained in this study are important for pharmaceutical industry since they strongly imply that chemical composition of A. milefolium EO significantly affects its anthelmintic properties. Thus, when using this oil for development of new anthelmintic drugs, the chemical composition of each EO sample should be strictly controlled, and only samples rich in 1,8-cineole and camphor should be chosen for further studies.

\section{CONCLUSION}

The present study revealed the in vitro ovicidal potential of two chemotypes of A. millefolium EO against the eggs of sheep GIN. The finding suggests that this essential oil is a promising candidate for further field examinations, which may be important for the development of new potential anthelmintic agents. However, the influence of various factors on EO chemical composition, such as plant material origin and method of EO isolation should not be 
neglected. Furthermore, this study highlights the possible importance of the use of medicinal plants and their products to control gastrointestinal parasites in ruminants, as well as their potential for general application in veterinary medicine. This may be of great interest in the era of anthelmintic resistance.

\section{ACKNOWLEDGEMENTS}

This work was part of the STSM (Short Term Scientific Mission) titled "The methodology of the diagnostics of parasitic infections and methods for evaluating the efficacy of antiparasitic drugs" of COST Action COMBAR (Combatting Anthelmintic Resistance in Ruminants), number CA16230. Special thanks to the STSM Coordinator Dr Maria Martinez-Valladares, who approved this STSM and the Grant Holder Dr Smaragda Sotiraki, who approved the financial support from the COST network for this STSM.

\section{Authors' contributions}

F.S.., R.R. and D.S. made substantial contributions to the basic idea, while the conduct of the research was made possible by I.P. and L.R.; R.R. and S.K. are responsible for the procurement of materials (essential oils) and the experiment was designed by F.Š., A.B. and L.R. Egg hatch test (taking samples from sheep, extraction of eggs, making preparations for incubation and reading the results) was conducted by F.Š., A.B. and A.A. with great advisory assistance from R.R., S.K., D.S. and L.R.; biochemical analyses were performed by N.S. and D.O., who also contributed to the draft of the manuscript. F.Š., R.R. and I.P. are responsible for interpreting the results and drawing conclusions, while the final version of the manuscript was drafted by F.S. with the assistance of all co-authors who revised the manuscript.

\section{Competing interests}

The authors declare that they have no competing interests for a work presented in the manuscript.

\section{REFERENCES}

1. Adams R.P. 2012. Identification of essential oil components by gas chromatography/mass spectrometry. $4^{\text {th }}$ edition, Allured Business Media, Illinois, USA.

2. André W.P.P., Ribeiro W.L.C., de Oliveira L.M.B., Macedo I.T.F., Rondon 
F.C.R., Bevilaqua C.M.L. 2018. Essential oils and their bioactive compounds in the control of gastrointestinal nematodes of small ruminants. Acta Scientiae Veterinariae, 46, 1522, 1-14, doi:10.22456/1679-9216.81804.

3. Ahmadi-Dastgerdi A., Ezzatpanah H., Asgary S., Dokhani S., Rahimi E. 2017. Phytochemical, antioxidant and antimicrobial activity of the essential oil from flowers and leaves of Achillea millefolium subsp. millefolium. Journal of Essential Oil Bearing Plants, 20, 2, 395-409, doi: 10.1080/0972060X.2017.1280419.

4. Ali S.I., Gopalakrishnan B., Venkatesalu V. 2017. Pharmacognosy, phytochemistry and pharmacological properties of Achillea millefolium L.: a review. Phytotherapy Research, 31, 8, 1140-1161, doi: 10.1002/ptr.5840.

5. Bączek, K., Kosakowska, O., Przybył, J.L., Kuźma, P., Ejdys, M., Obiedziński, M., Węglarz, Z. 2015. Intraspecific variability of yarrow (Achillea millefolium L. s.l.) in respect of developmental and chemical traits. Herba Polonica, 61, 3, 37-52, doi: 10.1515/hepo-2015-0021.

6. Bahmani M., Abdi F., Adineh A., Hassanzadazar H., Eghbali B., GholamiAhangaran M., Rafieian-Kopaei M. 2014. The anti-leech effect of ethanolic extract of Achillea millefolium L. compared to levamisole and niclosamide on Limnatis nilotica. Studia Universitatis Vasile Goldis, 24, 3, 293-297.

7. Barra A. 2009. Factors affecting chemical variability of essential oils: a review of recent developments. Natural Products Communications, 4, 8, 1147-1154.

8. Borgsteede F.H.M., Dercksen D.D., Huijbers R. 2007. Doramectin and albendazole resistance in sheep in the Netherlands. Veterinary Parasitology, 144, 1-2, 180-183, doi: 10.1016/j.vetpar.2006.09.031.

9. Bosco A., Maurelli M.P., Ianniello D., Morgoglione M.E., Amadesi A., Coles G.C., Cringoli G., Rinaldi L. 2018. The recovery of added nematode eggs from horse and sheep faeces by three methods. BMC Veterinary Research, 14, 1, 7, doi: 10.1186/s12917-017-1326-7.

10. Butnariu M., Sarac I. 2018. Essential oils from plants. Journal of Biotechnology and Biomedical Science, 1, 4, 35-43, doi: 10.14302/issn.2576-6694. jbbs-18-2489.

11. Camurça-Vasconcelos A.L.F., Bevilaqua C.M.L., Morais S.M., Maciel M.V., Costa C.T.C., Macedo I.T.F., Oliveira L.M.B., Braga R.R., Silva R.A., Vieira L.S. 2007. Anthelmintic activity of Croton zehtneri and Lippia sidoides essential oils. Veterinary Parasitology, 148, 3-4, 288-294, doi: 10.1016/j. vetpar.2007.06.012.

12. D`Ambola M., Bosco A. Ariano A, Rinaldi L, Bader A, Amadesi A, Cringoli G, Severino L. 2018. In vitro anthelminthic efficacy of Hypoestes for- 
skaolii (Vahl) R.Br (Acanthaceae) extracts on gastrointestinal nematodes of sheep. Veterinary Sciences, 5, 4, 89, doi: 10.3390/vetsci5040089.

13. Djouahri A., Boualem S., Boudarene L., Baaliouamer A. 2015. Geographic's variation impact on chemical composition, antioxidant and anti-inflammatory activities of essential oils from wood and leaves of Tetraclinis articulata (Vahl) Masters. Industrial Crops and Products, 63, 138-146. doi: 10.1016/j.indcrop.2014.10.018.

14. Dolinská M., Ivanišinová O., Königová A., Várady M. 2014. Anthelmintic resistance in sheep gastrointestinal nematodes in Slovakia detected by invitro methods. BMC Veterinary Research, 10, 233, doi: 10.1186/s12917014-0233-4.

15. El-Kalamouni C., Venskutonis P.R., Zebib B., Merah O., Raynaud C., Talou T. 2017. Antioxidant and antimicrobial activities of the essential oil Achillea millefolium L. grown in France. Medicines (Basel), 4, 2, 30, doi: 10.3390/medicines4020030.

16. Ferreira L.E., Benincasa B.I., Fachin A.L., França S.C., Contini S.S.H.T., Chagas A.C.S., Beleboni R.O. 2016. Thymus vulgaris L. essential oil and its main component thymol: Anthelmintic effects against Haemonchus contortus from sheep. Veterinary Parasitology, 228, 70-76, doi: 10.1016/j. vetpar.2016.08.011.

17. Ferreira L.E., Benincasa B.I., Fachin A.L., Contini S.H.T., França S.C, Chagas A.C.S., Beleboni R.O. 2018. Essential oils of Citrus aurantifola, Anthemis Nobile and Lavandula Officinalis: in vitro anthelmintic activities against Haemonchus contortus. Parasites \& Vectors, 11, 1, 269, doi: 10.1186/ s13071-018-2849-x.

18. Guz L., Adaszek Ł., Wawrzykowski J., Ziętek J., Winiarczyk S. 2019. In vitro antioxidant and antibabesial activites of the extracts of Achillea millefolium. Polish Journal of Veterinary Sciences, 22, 2, 369-376, doi: 10.24425/ pjvs.2019.129230.

19. Hoste H., Torres-Acosta J.F., Alonso-Diaz M.A., Brunet S., Sandoval-Castro C., Adote S.H. 2008. Identification and validation of bioactive plants for the control of gastrointestinal nematodes in small ruminants. Tropical Biomedicine, 25, 1 Suppl, 56-72.

20. Kaplan R.M. 2020. Biology, epidemiology, diagnosis and management of anthelmintic resistance in gastrointestinal nematodes of livestock. Veterinary Clinics of North America Food Animal Practice, 36, 1, 17-30, doi: 10.1016/j.cvfa.2019.12.001.

21. Katiki L.M., Chagas A.C.S., Bizzo H.R., Ferreira J.F.S., Amarante A.F.T. 2011. Anthelmintic activity of Cymbopogon martini, Cymbopogon schoe- 
nanthus and Mentha piperita essential oils evaluated in four different in vitro tests. Veterinary Parasitology, 183, 1-2, 103-108, doi: 10.1016/j.vetpar.2011.07.001.

22. Kebede A. 2019. Review on anthelmintic drug resistance nematodes and its methods of detection in Ethiopia. Journal of Veterinary Medicine and Animal Sciences, 2, 1, 1013.

23. Lans C., Turner N., Khan T., Brauer G., Boepple W. 2007. Ethnoveterinary medicines used for ruminants in British Columbia, Canada. Journal of Ethnobiology and Ethnomedicine, 3, 11, 1-22, doi: 10.1186/1746-4269-3-11.

24. Luna E.C., Luna I.S., Scotti L., Monteiro A.F.M., Scotti M.T., de Moura R.O., de Araújo R.S.A., Monteiro K.L.C., de Aquino T.M., Ribeiro F.F., Mendonça F.J.B. 2019. Active essential oils and their components in use against neglected diseases and arboviruses. Oxidative Medicine and Cellular Longevity, 2019, 6587150, doi: 10.1155/2019/6587150.

25. Macedo I.T.F., Bevilaqua C.M.I, de Oliveira L.M.B, Camurça-Vasconcelos A.L.F., Vieira L.S., Oliveira F.R., Queiroz-Junior E.M., Tome A.R., Nascimento N.R.F. 2010. Anthelmintic effect of Eucalyptus staigeriana essential oil against goat gastrointestinal nematodes. Veterinary Parasitology, 173, 1-2, 93-98, doi: 10.1016/j.vetpar.2010.06.004.

26. Macedo I.T.F, de Oliveira L.M.B., Andre W.B.P., Filho J.V.A., dos Santos J.M.L., Rondon F.C.M., Ribeiro W.L.C., Camurça-Vasconcelos A.L.F., de Oliveira E.F., de Paula H.C.B., Bevilaqua C.M.L. 2019. Anthelmintic effect of Cymbopogon citratus essential oil and its nanoemulsion on sheep gastrointestinal nematodes. Brazilian Journal of Veterinary Parasitology, 28, 3, 522-527, doi: 10.1590/S1984-29612019065.

27. Ministry of Agriculture, Fisheries and Food (MAFF), Grande-Bretagne, 1986. Manual of veterinary parasitological laboratory techniques. H.M. Stationery Off, London, UK.

28. Majid M., Roshan M., Andleeb L., Bhat M.I. 2018. Achillea millefolium L.: a promising health aid in modern pharmacology. International Journal of Advance Research in Science and Engineering, 7, 4, 2167-2182.

29. Mavrot F., Hertzberg H., Torgerson P. 2016. First assessment of production losses due to nematode infection in European dairy cattle and meat sheep. In: Mavrot F. Livestock nematode infection in a changing world: investigating the European situation. University of Zurich, Vetsuisse Faculty, p. 70-130.

30. Mesquita M.A., Júnior J.B.E.S., Panassol A., Oliveira E.F., Vasconcelos A.L.C.F., Paula H.C.B., Bevilaqua C.M.L. 2013. Anthelmintic activity of Eucalyptus staigeriana encapsulated oil on sheep gastrointestinal nematodes. Parasitology Research, 112, 9, 3161-3165, doi: 10.1007/s00436-013- 
3492-2.

31. Oliveira G.L., Vieira T.M., Nunes V.F., Ruas M.O., Duarte E.R., Moreira D.L., Kaplan M.A.C., Martins E.R. 2014. Chemical composition and efficacy in the egg-hatching inhibition of essential of Piper aduncum against Haemonchus contortus from sheep. Brazilian Journal of Pharmacognosy, 24, 2014, 288-292, doi: 10.1016/j.bjp.2014.07.004.

32. Özbilgin A., Durmuskahya C., Kilimcioğlu A.A. Kayalar H., Kurt O., Ermiş V., Tabak T. Östan I. 2013. In vitro efficacy of Quercus infectoria Oliv. and Achillea millefolium L. extracts against blastocystis spp. isolates. Kafkas Üniversitesi Veteriner Fakültesi Dergisi, 19, 3, 511-516, doi: 10.9775/ kvfd.2012.8196.

33. Papadopoulos E., Gallidis E., Ptochos S. 2012. Anthelmintic resistance in sheep in Europe: A selected review. Veterinary Parasitology, 189, 1, 85-88, doi: 10.1016/j.vetpar.2012.03.036.

34. Peña-Espinoza M. 2018. Drug resistance in parasitic helminths of veterinary importance in Chile: status review and research needs. Austral Journal of Veterinary Sciences, 50, 2, 65-76, doi: 10.4067/S071981322018000200065 .

35. Pinto N.B., de Castro L.M., Azambuja R.H.M., Capella G.D.A., de Moura M.Q., Terto W.D., Freitag R.A., Jeske S.T., Villela M.M., Cleff M.B., Leite F.P.L. 2019. Ovicidal and larvicidal potential of Rosmarinus officinalis to control gastrointestinal nematodes of sheep. Brazilian Journal of Veterinary Parasitology, 28, 4, 807-811, doi: 10.1590/S1984-29612019060.

36. Pljevljakušić D., Ristić M., Šavikin K. 2017. Screening of yarrow (Achillea millefolium Agg.) populations in Serbia for yield components and essential oil composition. Lekovite Sirovine, 37, 25-32, doi: 10.5937/leksir1737025P.

37. Qi H., Wang W.X., Dai J.L., Zhu L. 2015. In vitro Zanthoxylum simulans essential oil against Haemonchus contortus. Veterinary Parasitology, 211, 3-4, 223-227, doi: 10.1016/j.vetpar.2015.05.029.

38. Robles-Perez D., Martinez-Perey J.M., Rojo-Vazguez F.A., Martinez-Valladares M. 2014. Development of an egg hatch assay for the detection of anthelmintic resistance to albendazole in Fasciola hepatica isolated from sheep. Veterinary Parasitology, 203, 1-2, 217-221. doi: 10.1016/j.vetpar.2013.11.020.

39. Santoro G.F., Cardoso M.G., Guimarães L.G., Mendonça L.Z., Soares M.J. 2007. Trypanosoma cruzi: activity of essential oils from Achillea millefolium L., Syzygium aromaticum L. and Ocimum basilicum L. on epimastigotes and trypomastigotes. Experimental Parasitology, 116, 3, 283-290, doi: 10.1016/j.exppara.2007.01.018.

40. Sargison N.D., Scott P.R., Jackson E. 2001. Multiple anthelmintic resistance 
in sheep. The Veterinary Record, 149, 25, 778-779.

41. Sargison N. 2008. Sheep flock health: a planned approach. Wiley-Blackwell, New Jersey, USA, $1^{\text {st }}$ edition.

42. Simin S., Simin V., Kuruca Lj., Savović M. 2014. Preliminary evidence of ivermectin resistance in sheep gastrointestinal strongyles in Serbia. In Book of Abstracts, XVI Epizootiology days of Serbia, Zrenjanin, 06-07. September 2014, Srpsko veterinarsko društvo, edited by Tamaš Petrović, p. 126.

43. Soosaraei M., Fakhar M., Teshnizi S.H., Hezarjaribi H.Z., Banimostafavi E.S. 2017. Medicinal plants with promising antileishmanial activity in Iran: a systematic review and meta-analysis. Annals of Medicine and Surgery, 21, 63-80, doi: 10.1016/j.amsu.2017.07.057.

44. Sweeney T., Hanrahan J.P., Ryan M.T., Good R.B. 2016. Immunogenomics of gastrointestinal nematode infection in ruminants - breeding for resistance to produce food sustainably and safely. Parasite Immunology, 38, 9, 69-586, doi: 10.1111/pim.12347.

45. Štrbac F., Bosco A., Amadesi A., Rinaldi L., Stojanović D., Simin N., Orčić D., Pušić I., Krnjajić S., Ratajac R. 2020. In vitro ovicidal effect of common juniper (Juniperus communis L.) essential oil on sheep gastrointestinal nematodes. Veterinarski Pregled, 1, 1, 152-159.

46. Tariq K.A., Chishti M.Z., Bhat F.A., Shawl A.S. 2008. Anthelmintic efficacy of Achillea millifolium against gastrointestinal nematodes of sheep: In vitro and in vivo studies. Journal of Helminthology, 82, 3, 227-233, doi: 10.1017/ S0022149X08972515.

47. van Wyk J.A. and Mayhew E. 2013. Morphological identification of parasitic nematode infective larvae of small ruminants and cattle: a practical lab guide. The Onderstepoort Journal of Veterinary Research, 80, 1, E1-E14, doi: 10.4102/ojvr.v80i1.539.

48. Zeineldin M., Abdelmegeid M., Barakat R., Ghanem M. 2018. A review: herbal medicine as an effective therapeutic approach for treating digestive disorders in small ruminants. Alexandria Journal of Veterinary Sciences, 56, 1, 33-44, doi: 10.5455/ajvs.286678.

49. Zhu L., Dai J.L., Yang L., Qiu J. 2013. In vitro ovicidal and larvicidal activity of the essential oil of Artemisia lancea against Haemonchus contortus (Strongylida). Veterinary Parasitology, 195, 1-2, 112-117, doi: 10.1016/j. vetpar.2012.12.050. 